Ewa JURGA-WOSIK

Uniwersytet im. Adama Mickiewicza, Poznań

\title{
Unia Europejska na lamach drukowanej prasy lokalnej
}

Publikacje dotyczące Unii Europejskiej na łamach prasy lokalnej po raz
pierwszy ukazały sie w poczatkach lat dziewiećdziesiatych. Przekazy te miały charakter ukryty, tzn. nie zawierały wprost informacji o funkcjonowaniu Unii Europejskiej. Kampania polityczna nasycania prasy lokalnej wiadomościami o UE rozpoczęła się w momencie zawierania na szeroką skalę deklaracji o współpracy poszczególnych polskich miast z miastami państw członkowskich UE (tzw. „miasta partnerskie” lub „miasta bliźniacze”) ${ }^{1}$. Natomiast informacja bezpośrednia dotycząca UE pojawiła się w II połowie lat dziewięćdziesiątych, a jej znaczenie rosło (wzrost ilościowy i jakościowy tego typu informacji na łamach prasy) wraz z postępem negocjacji dotyczących wstapienia Polski do Unii Europejskiej. Warto przy tym nadmienić, że okres ten charakteryzował się też wzrostem ilości prywatnych tytułów lokalnych na rynku prasowym. W tym czasie prywatna prasa lokalna stała się poważnym konkurentem dla prasy wydawców samorządowych oraz ukazujących się pod patronatem różnych stowarzyszeń i instytucji kulturalnych. Należy podkreślić, że jednym z wyznaczników owej konkurencyjności był sposób przedstawiania wiadomości o Unii Europejskiej. Powszechnie wiadomo, iż zawartość treści jest w dużej mierze wynikiem uwikłania struktury redakcyjnej w politykę lokalną ${ }^{2}$. I stąd informacja zawarta w przekazie oraz konstrukcja i oprawa graficzna publikacji różnicują o typie wydawców. Kolejnym etapem kształtowania wizerunku UE na łamach prasy lokalnej była kam-

Szerzej E. Jurga, Miasta i gminy partnerskie na łamach prasy lokalnej Ziemi Leszczyńskiej, w: Przemiany polityczne w Polsce a integracja z Unia Europejska, pod red. A. Stelmacha, Poznań 2001, s. 9-24.

2 Szerzej E. Jurga, Ograniczenia niezależności w układzie dziennikarz-redaktor naczelny - wydawca (właściciel) w prasie lokalnej, „Środkowoeuropejskie Studia Polityczne" 2005, nr 1, s. 59-70; Własność medialna i jej wptyw na pluralizm oraz niezależność mediów, pod. red. B. Klimkiewicz, Kraków 2005, s. 49-89. 
pania akcesyjna. Krótko po wynikach referendum akcesyjnego wydawcy lokalni świadomi efektu zmęczenia czytelnika ową tematyką wstrzymali publikacje prounijne bądź ograniczyli się do notatek i wzmianek. Prasa lokalna na tym etapie wydawałoby się, że przygotowuje się do rozpoczęcia kampanii na rzecz wyborów do Parlamentu Europejskiego. Niestety ta na łamach prasy lokalnej, przebiegała niemal bez echa. Potwierdziła pewien schemat zamieszczania tego typu informacji w prasie lokalnej, który to jest niezmienny w przypadku wszelakich kampanii wyborczych ${ }^{3}$.

Konstrukcja i zawartość treści obejmujących informacje o Unii Europejskiej w prasie lokalnej to powielenie schematu tego typu wiadomości zawartych $\mathrm{w}$ mediach o zasięgu ogólnopolskim. Jednakże obraz UE w prasie lokalnej jest dostosowany do czynników kształtujących potencjalnego czytelnika. A zatem poszczególne redakcje brały głównie pod uwagę uśredniony stopień wykształcenia czytelnika oraz specyfikę danego regionu pod względem dominacji wykonywania zawodu (np. rolnicy). W przekazach kładziono nacisk na skondensowaną informację dotyczącą funkcjonowania instytucji wspólnotowych, opierającą się na wiedzy zawartej w leksykonach czy encyklopediach. Natomiast najbardziej nurtujące kwestie łączono z łamaniem stereotypów. Wiadomości były przekazywane najczęściej w formie notatek, wzmianek i komunikatów, czyli gatunki informacyjne przeważały nad publicystyką. Zawartość treści świadczy o prounijnym nastawieniu dziennikarzy, jak i samorządu terytorialnego. Można doszukać się tutaj wątków porozumienia w tej sprawie pomiędzy lokalnymi elitami a dziennikarzami. Generalnie należy stwierdzić, że zarządzanie mediami w tej oto kwestii, to porozumienie zawarte pomiędzy dziennikarzami i politykami. Współpracę tę można dostrzec w różnych formach kontaktowania się polityków z dziennikarzami, poprzez m.in. przygotowywanie przez tych pierwszych - informacji prasowych i konferencji. Ze strony mediów zaś pojawił się nacisk na relacjonowanie wydarzeń, w których biorą udział politycy. Próba wpływu na postawy wobec UE wykorzystywana na łamach prasy lokalnej jest widoczna w swoistym uwikłaniu tematyki integracji w bieżące sprawy społeczności lokalnej. Pozytywna opinia na temat integracji jest przekazywana w nieco zawoalowany sposób, w celu utrzymania zasad obiektywizmu dziennikarskiego. Przekaz uwypukla w subtelny sposób pozytywne aspekty integracji

3 Szerzej E. Jurga, Prasa lokalna w kampaniach politycznych, w: Kulturowe instrumentarium wolności, pod red. R. Paradowskiego, Poznań 2004, s. 115-123. 
i dzieje się tak dlatego, że informacje przekazywane w gazetach lokalnych są weryfikowalne ad hoc, co wyklucza przesadne koloryzowanie treści przekazu. Kanały komunikowania skupiają się na grupach potencjalnych przeciwników lub osób mających ambiwalentną postawę wobec Unii Europejskiej. Wykorzystuje się tutaj siłę opiniotwórczą autorytetów, jak i pozytywne opinie wygłaszane w komentarzach „osób z sąsiedztwa”. Taki zabieg ma stworzyć przekonanie o pozytywnej postawie wobec integracji wśród większości „Zwykłych ludzi”, będących w podobnej sytuacji społeczno-ekonomicznej. Przykładem na powyższe rozważania może być zawartość treści tygodnika „Panorama Leszczyńska”. Tytuł ten jest najdłużej istniejącym czasopismem w południowo-zachodniej Wielkopolsce ${ }^{4}$. Przeprowadzone badania ankietowe pozwalają stwierdzić, że jest on najbardziej rozpoznawalnym tytułem na obszarze byłego województwa leszczyńskiego $^{5}$. „Panorama Leszczyńska” jest identyfikowana również jako patron medialny wielu politycznych wydarzeń.

Pierwsze informacje dotyczące UE w „Panoramie Leszczyńskiej” miały miejsce w początkach lat dziewięćdziesiątych i były związane z powstawaniem miast partnerskich. Kolejne - pojawiły się w związku z kampanią akcesyjną. Ta na łamach „Panoramy Leszczyńskiej” rozpoczęła się w marcu 2003 roku. Była skierowana zwłaszcza do rolników i ludzi

4 Pierwszy numer „Panoramy Leszczyńskiej” ukazał się dnia 14 grudnia 1979 roku z inicjatywy Komitetu Wojewódzkiego PZPR. Redaktorem naczelnym pisma został Adam Zając. Tytuł ten wydawała RSW Prasa-Książka-Ruch, Warszawa. Początkowo nakład pisma sięgał 20 tys. egz. i dość szybko wzrastał, a dzisiaj wynosi 60 tys. egzemplarzy. Od 1992 r. redaktorem naczelnym jest Roman Majewski. W latach 1992-1998 pismo tłoczyła Spółdzielnia Wydawnicza „Panorama” w Lesznie, a od 1998 „Panorama” sp. z o.o., której prezesem został również Roman Majewski. Pismo obecnie wychodzi w formacie B-4 i liczy średnio 56 stron (zaczynało od 16). Posiada stałe rubryki m.in. Powiat, Region, Rolnictwo, a także nieregularne - Bliżej Unii, Kontrowersje czy okazjonalne - Wybory, Referendum. Większość tytułów południowo-zachodniej Wielkopolski nie przekracza tysiąca nakładu i są to zwykle miesięczniki. Zatem jedynym, poważnym konkurentem może być „Dziennik ABC”. Pismo to ukazuje się od 1990 r. (początkowo pięć razy w tygodniu, obecnie dwa razy) w 45 tys. jednorazowego nakładu. Respondenci rzadko wskazywali na ten tytuł. Przeciętny obywatel nie ma nawyku regularnego zakupu dziennika (nie tylko lokalnego), a w rezultacie nie jest przyzwyczajony do czytania prasy z taką częstotliwością. Kolportaż pism lokalnych głównie opiera się na sprzedaży w sklepach i prywatnych kioskach. Tygodnik „PL” rozprowadzany jest również przez m.in. sieć „RUCH” S.A., Pocztę Polską, ROLKON i KOLPORTER.

5 Badania własne 2002/2003 r. 
młodych (młodzież w wieku gimnazjalnym i licealnym). Powstały też artykuły dla czytelnika uniwersalnego i specyficznego jak - biznesmeni, muzealnicy i osoby niepełnosprawne fizycznie. Jednak te kategorie społeczne miały mniejszą reprezentację publikacji o tematyce unijnej, aniżeli rolnicy i młodzież szkolna. Wybór ten nie był przypadkowy, duży odsetek społeczności południowo-zachodniej Wielkopolski zajmuje się rolnictwem. Ponadto miasta byłego województwa leszczyńskiego współpracują od początku lat dziewięćdziesiątych z gminami z obszaru Unii Europejskiej ${ }^{6}$. Porozumienia miast partnerskich realizowane były głównie poprzez wymianę młodzieży szkolnej. Uczniowie zadowoleni z takiej formy współpracy, w ramach własnych szkół założyli szereg organizacji pogłębiających wiedzę o krajach UE i wspierających tym samym przystapienie Polski do Unii Europejskiej. Stąd też kierunek przekazu perswazyjnego.

„Panorama Leszczyńska” stosowała atrybut wiarygodności (godna zaufania, wypowiedzi ekspertów) w przekazach perswazyjnych ${ }^{7}$. Powoływano się również na dane (dotyczące głosowania za przystąpieniem Polski do UE) zamieszczane w sondażach bądź wynikach wyborów przedreferendalnych ${ }^{8}$. Te ostatnie miały miejsce niemal w każdej średniej szkole na obszarze byłego województwa leszczyńskiego. Istotnym elementem potwierdzającym kompetencje i dobrą intencję „Panoramy Leszczyńskiej” stanowi opublikowanie wyników referendum, uzupełnionych komentarzem przeciętnych mieszkańców badanego obszaru' ${ }^{9}$. Obiektywizm pojawił się w przedstawianiu opcji „,za” i „,przeciw” UE, z tym że zachwiana została tutaj równowaga pomiędzy stronami, na korzyść tej pierwszej. Na 70 publikacji, tylko 4 odnosiły się negatywnie do przystapienia Polski do Unii Europejskiej. Był to zatem pozorny obiektywizm w dziennikarskiej selekcji materiałów. „Panorama Leszczyńska” patronując konkursom o wiedzy z zakresu UE określiła tym samym swój stosunek do tej sprawy ${ }^{10}$. Stosowała wyważony przekaz perswazyjny, znając

6 Niemalże wszystkie gminy leszczyńskie nawiązały kontakt z miastami państw Unii Europejskiej (na 24 miasta aż 23 podpisały umowę - wyjątek stanowiła gmina Wijewo).

Raj czy ruina?, „Panorama Leszczyńska” 2003, nr 21, s. 23; Trening przed Unia, „Panorama Leszczyńska”, nr 19, s. 2.

8 Dwie trzecie za, „Panorama Leszczyńska” 2003, nr 15, s. 22; 58 proc. za przystapieniem, „Panorama Leszczyńska” 2003, nr 13, s. 25; Unii powiedzieli tak, „Panorama Leszczyńska” 2003, nr 15, s. 22.

9 Por. „Panorama Leszczyńska” 2003, nr 24, s. 8.

10 Europa bez tajemnic, „Panorama Leszczyńska” 2003, nr 15, s. 22; Zjednoczona Europa bez tajemnic, „Panorama Leszczyńska” 2003, nr 21, s. 23. 
dobrze swoich czytelników. Zauważalne to było w doborze grup docelowych i rozmieszczeniem treści na stronie pisma. Warto też wspomnieć, że odbiorcy podkreślali cechę bezstronności, co zwiększało siłę perswazji pisma. Czytelnicy więc, byli przekonani, że nikt nie stara się na nich wpływać $^{11}$. Tymczasem - „Panorama Leszczyńska” była nadawcą uwikłanym w sieć komunikowania politycznego, co jest typowe zwłaszcza dla mediów lokalnych. Dziennikarze na łamach „Panoramy Leszczyńskiej” opisywali swój udział w konferencjach poświęconym mediom, organizowanych pod patronatem prezydenta i rządu. Dziennikarze lokalni stali się pośrednikami w przekazywaniu idei przystąpienia Polski do UE pomiędzy władzą najwyższą a społeczeństwem. Przykładów można się doszukiwać, np. w udziale prasy lokalnej w konferencjach poświęconych „miastom partnerskim”, organizowanym przez MSZ i MSWiA (lata dziewięćdziesiąte) i konferencjach prasowych z udziałem prezydenta, czy znanych polityków nawołujących do głosowania na „tak” w referendum akcesyjnym (przekazy marzec-maj 2003 r.) ${ }^{12}$. Politycy zdają sobie sprawę z siły mediów lokalnych, wynikającej z pisania o rzeczach bliskich społecznościom przez dziennikarzy z ich otoczenia. Skuteczność oddziaływania informacji jest zależna zatem od wiarygodności źródła jej pochodzenia oraz autorów publikacji. A ta jest w dużej mierze uzależniona od autorytetu, na który autor powołuje się w publikacji. Zatem im wyższy jest stopień zaufania odbiorcy do autorytetu, tym większy może być wpływ takiej informacji na zmianę jego postawy. Autorzy publikacji, szczególnie - współpracownicy (korespondenci), cieszą się większym autorytetem moralnym niż dziennikarze „na etacie” z racji tego, iż przede wszystkim pełnią poważane w środowisku lokalnym funkcje czy profesje (np. przedstawiciele placówek oświatowych, kulturalnych). Warto też podkreślić udział korespondentów i czytelników w procesie zbierania informacji, co decyduje o różnorodności treści i podnoszeniu stopnia zainteresowania tytułem wśród społeczności lokalnej. Jak wiadomo dziennikarze

11 Badania własne.

12 Keine Grenzen!, „Panorama Leszczyńska”, nr 22, s. 4; Przekonywał i zapewniat, „Panorama Leszczyńska” 2003, nr 20, s. 22; Najgorzej wcale, „Panorama Leszczyńska” 2003, nr 22, s. 9; Nie utopmy tej szansy, „Panorama Leszczyńska” 2003, nr 18, s. 9; Unia jak remedium, „Panorama Leszczyńska” 2003, nr 16, s. 8; Wiceminister zamiast wicepremiera, „Panorama Leszczyńska” 2003, nr 20, s. 9; Wierze w madrość Wielkopolan, „Panorama Leszczyńska” 2003, nr 23, s, 17; Wsiaśś do pociagu, „Panorama Leszczyńska” 2003, nr 22, s. 4. 
lokalni często ze względu na ograniczone możliwości finansowe i materialne (wyposażenie redakcji) pozyskują informacje zwykle drogą pośrednią, a bezpośredniość dotyczy w takim układzie zwykle obróbki materiału (informacji). W rezultacie prasa lokalna sprawdza się jako przedmiot oddziaływania środowiska lokalnego, grup, jednostek na społeczność lokalna.

O skuteczności przekazywania informacji decyduje również jej treść (strona semantyczna wypowiedzi), forma (gatunki) i osobowość czytelnika. Treść nie może zbyt daleko odbiegać od postaw odbiorców. Wiadomości lokalne są odbierane pod kątem ich użyteczności. Funkcja informacyjna prasy lokalnej jest wówczas skuteczna, jeśli podnosi sprawy życia lokalnego, które są oczekiwane przez lokalnego odbiorcę. Należy jednak pamiętać, że informacja ma dwojaki charakter - odzwierciedla aktualne wydarzenia i jest ilustracją pewnego, rzeczywistego stanu rzeczy (zbliża się do publicystyki) ${ }^{13}$.

Odbiorca komunikatu prasowego nie powinien odczuć, iż jest uświadamiany przez nadawcę, szczególnie gdy nadawca ma na uwadze zmianę postaw odbiorców ${ }^{14}$. W takim przypadku komunikaty powinny prezentować argumentację dwustronną, gdyż jednostronna może utwierdzić czytelnika w jego dotychczasowym przekonaniu o niewiarygodności nadawcy. A zatem pozytywnym działaniem jest rozpoczęcie wiadomości od wspólnego stanowiska nadawcy i odbiorcy. Ponadto istotną rolę w procesach zmian odbiorców odgrywają mechanizmy tzw. dysonansu poznawczego, czyli dążenie do zdezintegrowania aktualnej postawy odbiorcy ${ }^{15}$. Realizują się one zwłaszcza poprzez wzbudzanie u odbiorcy silnego lęku czy negatywnych emocji i uczuć.

W „Panoramie Leszczyńskiej” tylko jeden artykuł mógł u czytelnika wzbudzić emocje, a dotyczył oficjalnych wyników referendum akcesyjnego (opisano gminę, która głosowała na „nie") ${ }^{16}$. Wbrew pozorom, ten artykuł umacniał wśród odbiorców decyzję o wyborze ,za”. Jednak materiały w kampanii akcesyjnej były stonowane. Położono główny nacisk na tworzenie i poprawianie wizerunku Unii Europejskiej. Odrzucano zarzuty powstałe wokół integracji Polski z UE (m.in. groźba wykupienia ziem

13 Szerzej o charakterystyce gatunków dziennikarskich - M. Wojtak, Gatunki prasowe, Lublin 2004.

${ }^{14}$ T. Mądrzycki, Warunki i metody zmiany postaw, w: Teorie postaw, pod red. S. Nowaka, Warszawa 1973, s. 330-331.

15 J. Mikułowski Pomorski, Z. Nęcki, Komunikowanie skuteczne?, Kraków 1983, s. 150.

16 Boja się $i$ wierza, „Panorama Leszczyńska” 2003, nr 25, s. 9. 
polskich przez obcy kapitał, zubożenia w przyszłości rolników oraz homogenizacji kultury) ${ }^{17}$. Podnoszono w prasie głównie ideę integracyjną $i$ historyczny rodowód Unii Europejskiej ${ }^{18}$. Ukazało się również szereg artykułów przedstawiających podstawy organizacji i funkcjonowania instytucji unijnych ${ }^{19}$. Stymulowano także aktywność obywateli poprzez ich zachęcanie do udziału w licznych konkursach z zakresu wiedzy o strukturach $\mathrm{UE}^{20}$. Informacja również miała wpływać na niezdecydowanych odbiorców. W związku z tym określano i redefiniowano kluczowe problemy polityczne związane z szeroko pojmowaną integracją Polski z Unią Europejską ${ }^{21}$. Umacniano poparcie dla idei integracji zamieszczając informacje o zaangażowaniu obywateli w propagowanie wiedzy o UE (nacisk na organizacje młodzieżowe, powoływanie się na ekspertów) i publikując wstępne sondaże wyników szkolnych tzw. przedreferendów oraz oficjalnych wyników komentowanych pozytywnie przez niezaangażowanych instytucjonalnie osób w sprawy Unii ${ }^{22}$.

Istotna jest też forma (gatunki) wypowiedzi prasowych, która wpływa na percepcję i zrozumienie komunikatu przez odbiorcę, a w rezultacie nastawia go pozytywnie lub negatywnie do nadawcy. Wypowiedzi prasowe w danym tytule lokalnym tworzą jego strukturę rodzajową i gatunkową. Ta natomiast jest nie tylko przybliżonym obrazem dziennikarskich sposobów pozyskiwania czytelników, ale także pełnienia przez prasę określonych funkcji w społeczności lokalnej. Gatunki dziennikarskie doczekały

17 Por. By nie stać się..., s. 18; O przeszłości dla przyszłości, „Panorama Leszczyńska” 2003, nr 21, s. 17.

18 Europejskie symbole, „Panorama Leszczyńska” 2003, nr 13, s. 25; ibidem, Unia kolorów; ibidem, Czwórpodziat władzy.

19 Między innymi: Cztery filary wspólnot, „Panorama Leszczyńska” 2003, nr 13, s. 25; Wspólne pieniqdze, „Panorama Leszczyńska” 2003, 15, s. 22.

20 Europa w sieci, „Panorama Leszczyńska” 2003, nr 24, s. 15; Zjednoczona Europa bez tajemnic, „Panorama Leszczyńska”, nr 17, s. 24; ibidem, Wędrówki po krajach Unii; ibidem, Kolejny sukces Nowaka; W nagrodę do Francji, „Panorama Leszczyńska" 2003, nr 24, s. 18.

21 Trzeba się spieszyć, „Panorama Leszczyńska” 2003, nr 23, s. 17.

22 Integracja $w$ integracji, „Panorama Leszczyńska” 2003, nr 15, s. 8; ibidem, Nie agituja, lecz informuja, s. 3; Nie deptać sumień, „Panorama Leszczyńska” 2003, nr 12, s. 4; Powiedzieli tak, „Panorama Leszczyńska” 2003, nr 17, s. 5; Unii powiedzieli tak, „Panorama Leszczyńska” 2003, nr 22, s. 8; ibidem, Europa bez tajemnic; Nie w referendum, „Panorama Leszczyńska” 2003, nr 13, s. 7; Młode centrum na tak, „Panorama Leszczyńska”, nr 17, s. 3; Szkoła po europejsku, „Panorama Leszczyńska” 2003, nr 22, s. 2; W nagrodę do Francji, „Panorama Leszczyńska” 2003, nr 24, s. 18. 
się wielu koncepcji teoretyczno-metodologicznych, próbujących objaśnić ich charakter ${ }^{23}$. Prasowe gatunki informacyjne pełnia przede wszystkim funkcję powiadamiania, a ich konstrukcja jest zwarta, rzeczowa i bliska faktom. Natomiast gatunki publicystyczne podporządkowane są funkcji interpretacyjnej i perswazyjnej. Przedstawiają, wyjaśniają i oceniają rzeczywistość. O ile informacja rozszerza o niej wiedzę, o tyle publicystyka ją pogłębia. W przeciwieństwie do publicystyki, gatunki informacyjne cechuje prosta budowa. Informację cechuje obiektywizm, jest przeznaczona dla ogółu, zawiera aktualny stan rzeczy oraz ma określoną formalną strukturę. Styl informacji ma charakter funkcjonalny i jest nastawiony na szerokie kręgi odbiorcze. W przekazie perswazyjnym powinna być właściwa proporcja pomiędzy elementami emocjonalnymi a argumentami racjonalnymi ${ }^{24}$.

W kampanii akcesyjnej przeważała informacja nad publicystyką. Gatunki informacyjne obejmowały w dużej mierze treści dotyczące elementarnej wiedzy o instytucjach unijnych, wydarzenia związane z rządową polityką prounijną $\mathrm{w}$ regionie i wskazówki odnośnie postępowania wyborcy w trakcie referendum. W jednej jak i w drugiej formie, szczególnie w zakresie tematycznym, budzącym największe kontrowersje - występował przekaz ukryty ${ }^{25}$. W tym kontekście przekaz ukryty służy powstawaniu postaw proeuropejskich, bazując na zachowaniach zdroworozsądkowych (racjonalnych), najczęściej argumentach finansowych. W przekazie ukrytym dominują informacje o charakterze przyczynowo-skutkowym i łatwo weryfikowane empirycznie. Prezentowanie skondensowanych wiadomości o pozytywnych stronach integracji Polski z UE, a także opisywanie sukcesów miast, danej branży (nagrody europejskie) lub poszczególnych

23 J. Maziarski, Metodologiczne problemy nauki o gatunkach dziennikarskich, w: Metody i techniki badawcze w prasoznastwie, t. 1, Warszawa 1969, s. 116; J. Maziarski, Problemy systematyzacji gatunków dziennikarskich, w: Metody i techniki badawcze $w$ prasoznastwie, t. II, Warszawa 1970, s. 77-104.

24 A. Stępińska, Reklama polityczna w środkach społecznego przekazu, w: Media $i$ polityka, pod red. J. Sobczaka, t. 1, Poznań 2001, s. 137.

25 Bardziej mineralnie niż sztucznie, „Panorama Leszczyńska” 2003, nr 13, s. 17; Darmowe szkolenie, „Panorama Leszczyńska” 2003, nr 17, s. 8; Europeistyka-modny kierunek, „Panorama Leszczyńska” 2003, nr 13, s. 25; Gesty H. Klosa, „Panorama Leszczyńska” 2003, nr 20, s. 3; Koniec korków granicznych, „Panorama Leszczyńska” 2003, nr 17, s. 24; Po dyplomie flaga, „Panorama Leszczyńska” 2003, nr 16, s. 7; Praca dla urzędników, „Panorama Leszczyńska” 2003, nr 17, s. 24; Zjednoczony patron, „Panorama Leszczyńska” 2003, nr 15, s. 22. 
osób z regionu leszczyńskiego (znanych w Europie) w promowaniu UE - miało dać nadzieję ludziom na podobny sukces bądź na lepsze życie ${ }^{26}$. Najbardziej popularnymi formami dziennikarskimi były - wzmianki, notatki, reportaże i wywiady.

O skuteczności oddziaływania należy też mówić w kontekście osobowości czytelnika. Tę kształtują takie czynniki jak - wiedza, poziom inteligencji, samoocena, potrzeby, podatność na sugestię czy wiek. Prasa lokalna oddziałując na osobowość odbiorców, kształtuje opinię publiczną. Składnikami procesu opiniotwórczego są: wyobrażenia o interesach grupowych, wzory kulturowe, stereotypy, mity, przesądy i uprzedzenia, a także pogłoski i plotki oraz wiedza o faktach ${ }^{27}$. Próbą obalenia mitów i uprzedzeń z dziedziny rolnictwa podnoszonych w trakcie kampanii akcesyjnej był wywiad z przedstawicielem branży rolniczej w Niemczech na łamach „Panoramy Leszczyńskiej” "28. Waga tego artykułu jest szczególna, gdyż z pozycji prounijnej wypowiadał się obywatel Niemiec, co w efekcie miało złamać stereotyp Niemca ,grabieżcy”, ciagle funkcjonujący w mentalności ludzi zamieszkujących tzw. „Ziemie Odzyskane”.

Na skuteczność oddziaływania ma również wpływ szata i układ graficzny pisma. Uwagę ludzi zwraca to, co - intensywne (jaskrawy kolor, czerń, pogrubiona czcionka), wyjątkowe (kontrast czcionek małych z większymi), powtarzalne (stałe rubryki), powiększone (duża ilustracja czy długi tekst) i urozmaicone (teksty o różnej wielkości występujące w sąsiedztwie $)^{29}$. Tygodnik „Panorama Leszczyńska” jest traktowany wśród respondentów jako jedyna ich opiniotwórcza lokalna gazeta. To przeświadczenie zastępuje wszelkie braki w szacie i układzie graficznym. Zatem wystarczy umiejętność zastosowania właściwych proporcji szpalt i światła. Czytelnicy nabywają „Panoramę Leszczyńską” z wielu powodów - mają zaufanie do treści przekazywanych na jej łamach, jest najdłużej ukazującym się periodykiem $\mathrm{w}$ regionie i pismo aktywnie uczestniczy w lokalnych wydarzeniach społeczno-politycznych.

26 Europa w sieci, „Panorama Leszczyńska”, nr 24, s. 15; Kolejny sukces Nowaka, „Panorama Leszczyńska” 2003, nr 17, s. 24; Z listy lub z zaświadczeniem, „Panorama Leszczyńska” 2003, nr 21, s. 23; Za krzewieniem idei, „Panorama Leszczyńska” 2003, nr 22 , s. 7.

27 S. Kuśmierski, Opinia publiczna. Wstęp do teorii, Warszawa 1997, s. 29-59.

28 M. Papież, By nie stać się zaściankiem Europy, „Panorama Leszczyńska” 2003, nr 15 , s. 18.

29 W. Pisarek, Podstawy retoryki dziennikarskiej, w: Dziennikarstwo i świat mediów, Kraków 2000, s. 219. 
Tytuły i nadtytuły w „Panoramie Leszczyńskiej” nawiązywały treścią do grup celowych wyznaczonych w kampanii referendalnej [młodzież - np. - „Unijnie i rockowo”30 „Europa w sieci”, ${ }^{31}$, „O przeszłości dla przyszłości”,32, „,Szkoła po europejsku”33 ${ }^{\prime 3}$ rolnicy - np. „By nie stać się zaściankiem Europy”,34, „Z pomocą SAPARDU”35, „Unijne normy i dopłaty”,36, „Nie dajmy się zgładzić”,37; różne grupy zawodowe - np. „Marketing historyczny” (muzealnicy) ${ }^{38}$, ,Kupcy na eksport" ${ }^{39}$; odbiorca uniwersalny - np. „Wybór na lata” ${ }^{40}$, „Nie utopmy tej szansy”41, „Unia jak remedium,"42].

Z przytoczonych tytułów wynika pewna strategia doboru grupy adresatów, na którą to gazety lokalne chcą wpływać. Można wyróżnić co najmniej dwie takie grupy. Należą do nich młodzież i rolnicy. Generalnie informacje dotyczące relacji młodzież - integracja z UE, pojawiały się w kontekście inicjatyw uczniów szkół gimnazjalnych i średnich. Informowanie w takiej formie miało spełniać dwa cele. Pierwszym z nich jest nawiązanie do czytelników nie należących do grupy młodzieży. Zamieszczając informacje o UE w kontekście wydarzeń związanych z inicjatywami młodzieżowymi - prasa w rezultacie oddziałuje na postawy czytelników, a zwłaszcza rodziców. Ponadto tworzy się na łamach pisma przekonanie, że UE jest związana z rozwojem, ewolucją i szansą dla ludzi młodych. Taki sposób prezentacji prowadzi do wniosku, że integracja jest korzystna dla młodych ludzi i daje nadzieje na przyszłość. Informacje związane z młodzieżą dotyczyły zwykle kontaktów bezpośrednich, wymiany młodzieży szkolnej bądź inicjatyw na poziomie kulturalnym. Pojawienie się na łamach prasy lokalnej nazwisk, czy też rodzaju szkoły, która uczestniczy w określonej inicjatywie proeuropejskiej podkreślało prestiż zarówno

\footnotetext{
30 „Panorama Leszczyńska” 2003, nr 13, s. 15.

31 „Panorama Leszczyńska” 2003, nr 24, s. 15.

32 „Panorama Leszczyńska” 2003, nr 21, s. 17.

33 „Panorama Leszczyńska” 2003, nr 22, s. 2.

34 „Panorama Leszczyńska” 2003, nr 15, s. 18.

35 „Panorama Leszczyńska” 2003, nr 21, s. 9.

36 „Panorama Leszczyńska” 2003, nr 25, s. 9.

37 „Panorama Leszczyńska” 2003, nr 23, s. 17.

38 „Panorama Leszczyńska” 2003, nr 22, s. 24.

39 „Panorama Leszczyńska” 2003, nr 23, s. 17.

40 „Panorama Leszczyńska” 2003, nr 24, s. 8.

41 „Panorama Leszczyńska” 2003, nr 18, s. 9.

42 „Panorama Leszczyńska” 2003, nr 16, s. 8.
} 
szkoły, jak i rodziców. Drugim sposobem zamieszczania informacji o młodzieży w kontekście wpływu prasy lokalnej na kształtowanie postaw wobec UE było odwołanie się do młodzieży w bezpośredni sposób, poprzez artykuły związane $\mathrm{z}$ działalnością młodych ludzi. Jednakże ta forma kształtowania postaw samej młodzieży jest mniej efektywna chociażby z tego powodu, że młodzi ludzie nie są głównymi odbiorcami tego typu prasy. Pojawiające się informacje nie były atrakcyjne dla młodzieży ani $\mathrm{w}$ formie, ani w treści. Reasumując można stwierdzić, że poprzez zamieszczanie przez redaktorów informacji mających na celu kształtowanie pozytywnego wizerunku UE, wykorzystuje się młodzież jako pewien środek dotarcia do właściwych odbiorców, czyli osób starszych (zwykle rodziców). Informacje dotyczyły głównie młodzieży w wieku gimnazjalnym i licealnym, poprzez to można określać potencjalną grupę odbiorców na wiek ich rodziców, który oscyluje pomiędzy 40 a 50 rokiem życia.

Kolejną grupą docelową wyróżniającą się odnośnie ilości poświęconych jej informacji w kontekście integracji z UE podczas kampanii akcesyjnej byli rolnicy. Jest to grupa specyficzna, która z integracją wiąże dużo nadziei, jak i sporo obaw. Sposób dotarcia do rolników przez gazety lokalne ma nieco inny wymiar niż forma tego przekazu kierowana do młodzieży czy też de facto ich rodziców. O ile w przypadku informacji o działaniach związanych z aktywnością młodzieży dominował aspekt integracji z młodymi ludźmi mieszkającymi w krajach UE, o tyle w przypadku informacji przygotowywanych dla rolników w pierwszej kolejności prezentowano finansowy i edukacyjny aspekt członkostwa. Nie bez znaczenia miały również informacje zmierzające do niwelowania obaw tej grupy zawodowej związanych z potencjalnym zagrożeniem wykupem ziemi przez obywateli Unii Europejskiej. Dominowała argumentacja oparta na „głosach autorytetów", czyli wywiady ze specjalistami zajmującymi się tą problematyką w Brukseli, jak i zachęcanie do działań związanych z zasięganiem informacji na temat korzystania $z$ funduszy unijnych przeznaczonych na rolnictwo.

Z dużym dystansem prasa lokalna odnosiła się do kwestii integracji z Unią Europejską począwszy od 1990 r. do końca marca 2003 roku, a więc do momentu rozpoczęcia kampanii referendalnej. Zamieszczane były informacje o funkcjonowaniu lokalnych młodzieżowych klubów, zajmujących się propagowaniem wiedzy o strukturach europejskich. W niektórych czasopismach pojawiały się cyklicznie podstawowe wiadomości o organach Unii Europejskiej. Brak natomiast było żywej dyskusji na łamach prasy. Stąd trudno mówić, że prasa integrowała społeczność 
lokalną wokół tego problemu. Redaktorzy naczelni tytułów lokalnych świadomi po pierwsze - ekspansji wiadomości prounijnych w mediach ogólnopolskich i po drugie - zmęczenia tym tematem u odbiorcy, celowo nie zamieszczali w bezpośredni sposób tego rodzaju informacji. Co pewien czas podkreślali jednak, że temat ten jest ważny. Na łamach pism lokalnych pojawiały się natomiast informacje dotyczące miast partnerskich, które to de facto sprowadzały się do tego samego (informacja nie wprost) - promowania idei prounijnej ${ }^{43}$. Ostrożność ta wynikała z potrzeb i zaufania odbiorcy lokalnego do pisma.

Momentem przełomowym w ilości i formie stała się kampania akcesyjna. Uwidoczniła ona wagę problemu. Po referendum akcesyjnym, a przed rozpoczęciem kampanii wyborczej do Parlamentu Europejskiego nieznacznie zmalała ilość artykułów poświęconych UE, ale utrzymane zostały przekazy ukryte. Te również obecnie stosowane są w prasie lokalnej ${ }^{44}$. Pierwsze wybory do Parlamentu Europejskiego prasa lokalna potraktowała w znany już czytelnikom i badaczom sposób. Ograniczyła publikacje - tak jak w przypadku innych kampanii wyborczych do wiadomości instruktażowych (jak i gdzie głosować), zamieszczania reklam politycznych i wyników głosowania w poszczególnych gminach, będących obszarem zasięgu ukazywania się pisma. Po wyborach do Parlamentu Europejskiego, prasa lokalna sporadycznie zajmuje się problemami z zakresu Unii Europejskiej. Można sądzić, iż jest to zamierzone działanie nadawców lokalnych, bowiem ci obawiali się, szczególnie po kampanii akcesyjnej - efektu znużenia czytelnika tematyką unijną. Pomimo tego forma i treść kolejnych publikacji w prasie lokalnej nie odbiega od przyjętych wcześniej założeń redakcji, odnośnie informacji kształtujących obraz Unii Europejskiej ${ }^{45}$. Podobnie nie zmieniono grup odbiorców, do których

43 E. Jurga, Miasta i gminy partnerskie na łamach prasy lokalnej Ziemi Leszczyńskiej, w: Przemiany polityczne w Polsce a integracja z Unia Europejska, pod. red. A. Stelmacha, Poznań 2001, s. 9.

44 Pojechali za Socratesem, „Panorama Leszczyńska” 2005, nr 45, s. 8; Pozwala na milczenie, „Panorama Leszczyńska” 2005, nr 46, s. 6; Rasowe świnie, „Panorama Leszczyńska” 2005, nr 38, s. 13; Siatka międzynarodowa, „Panorama Leszczyńska” 2005, nr 45, s. 4; Stypendia rozdane, „Gazeta Kościańska” 2005, nr 47, s. 12; Trzy dni w Alzey - Worms, „Gazeta Kościańska” 2007, nr 37, s. 3; To nie koniec wspótpracy, „Gazeta Kościańska” 2008, nr 15, s. 6.

45 Pracuje i tańczy w Brukseli, „Panorama Leszczyńska” 2007, nr 33, s. 14; Rury najważniejsze, „Panorama Leszczyńska” 2005, nr 34, s. 6; ibidem, W trosce o stare drzewa, s. 8; ibidem, reklama z branży samochodowej, powołująca się na projekt 
skierowany jest przekaz. A zatem polityka kreowania wizerunku UE stała się celem długofalowym w mediach lokalnych. Zmieniało się tylko natężenie publikacji. I w związku z tym kampania polityczna propagująca UE rozpoczęła się w sposób widoczny w drugiej połowie lat dziewięćdziesiątych i trwa nieprzerwanie. Uważny czytelnik znajdzie w niej efekt porozumienia dziennikarzy z politykami, bynajmniej nie tylko lokalnymi. W ostatnim czasie w prasie lokalnej zmienia się nieznacznie wizerunek Unii Europejskiej. O ile - do dnia 1 maja 2004 roku, zamieszczany był w większości przekaz informujący o funkcjonowaniu instytucji wspólnotowych, to po tej dacie zauważalny jest wzrost publikacji akcentujących „walkę" o polskie interesy. W związku z tym kształtuje się wizerunek dualizmu UE, na zasadzie „my” i pozostałe państwa UE ${ }^{46}$. Poza tym od 2005 roku w prasie lokalnej regionu południowo-zachodniej Wielkopolski - przeważająca ilość informacji jest poświęcona pozyskiwaniu środków unijnych na inwestycje lokalne ${ }^{47}$. Można oczekiwać, iż zawartość tematyczna odnośnie spraw związanych z funkcjonowaniem Unii Europejskiej wzrośnie jakościowo i ilościowo w najbliższej kampanii wyborczej do Parlamentu Europejskiego w 2009 roku. Jednak przekazy te moga

współfinansowany ze środków UE [od aut.], s. 23; Nagrodzeni za jakość, „Panorama Leszczyńska" 2004, nr 14, s. 4; ibidem, Będzie nowy Ford, s. 5; ibidem, Agencja werbuje $i$ kontroluje, s. 5; ibidem, Wolowa ofensywa, s. 5; ibidem, Praktyczny wymiar przyjaźni, s. 7; por. stronę zatytułowaną - Bliżej Unii, „Panorama Leszczyńska” 2004, nr 15, s. 28; ibidem, stronę zatytułowaną - U sqsiadów, s. 19; ibidem, Sięganie do unijnej kasy, s. 4; ibidem, Misja na lata, s. 5, ibidem, Lubiq historie, patrzq w przysztość, s. 5; por. Unijna droższa od naszej, „Panorama Leszczyńska” 2004, nr 18, s. 8; ibidem, strona zatytułowana Blizej Unii, s. 24; ibidem, strona zatytułowana - Rolnictwo, s. 25; ibidem, kolorowy dodatek do „Panorama Leszczyńska” - „Gotowi do Unii”, s. 1-16.

46 Młodzież WszechEUROpejska, „Panorama Leszczyńska” 2005, nr 38, s. 9; Pozwala ..., „Panorama Leszczyńska” 2005, nr 46, s. 6; Tomograf na przeżycie, „Panorama Leszczyńska” 2005, nr 48, s. 4.

47 Czekają na Unię, „Panorama Leszczyńska” 2007, nr 41, s. 10; Czekaja na Unię, „Panorama Leszczyńska” 2008, nr 18, s. 9; ibidem, Dlugi w ryzach, s. 8; ibidem, Nie tylko elewacja, s. 9; Ekspert od funduszy, „Gazeta Kościańska” 2006, nr 36, s. 7; Inwestycje bez kredytów, „Panorama Leszczyńska” 2008, nr 17, s. 5; ibidem, Po jednej co roku, s. 6; ibidem, Rondo z dojazdami, s. 27; Komputery dla dwójki, „Gazeta Kościańska” 2005, nr 47, s. 13; Podziela pieniqdze, „Gazeta Kościańska” 2006, nr 23, s. 4; ibidem, Szkolenie dla rolników, s. 12; ibidem, Twój pomyst, twoja praca, s. 14; Twój pomyst, twoja praca, „Orędownik Powiatowy. Pismo Powiatu Kościańskiego” 2006, nr 8, s. 2; Tunele pod torami, „Orędownik Powiatowy. Pismo Powiatu Kościańskiego” 2006, nr 20, s. 1; Wydziszewo - Czacz do modernizacji, „Gazeta Kościańska” 2008, nr 15 , s. 9. 
powielać sposób i tematykę prezentacji wiadomości dziennikarskich i niedziennikarskich (głównie ogłoszeń i reklam politycznych) przyjęty w poprzednich kampaniach - akcesyjnej i parlamentarnej. Przypuszczenia takie wynikają z analizy dotychczasowych publikacji poświęconych Unii Europejskiej.

\section{Summary}

The first publications concerning the European Union appeared in the local press in the early 1990s. These messages were concealed, i.e. they did not provide direct information about the functioning of the EU. The political campaign to saturate local press with EU news commenced when Polish cities and towns commonly began to declare collaboration with the cities and towns in EU member states ('partner cities' or 'twin towns'). Direct announcements concerning the EU appeared in the late 1990s. The significance of this information was growing (that is a quantitative and qualitative increase of such releases in the press) as the negotiations on Poland's accession to the EU progressed. 